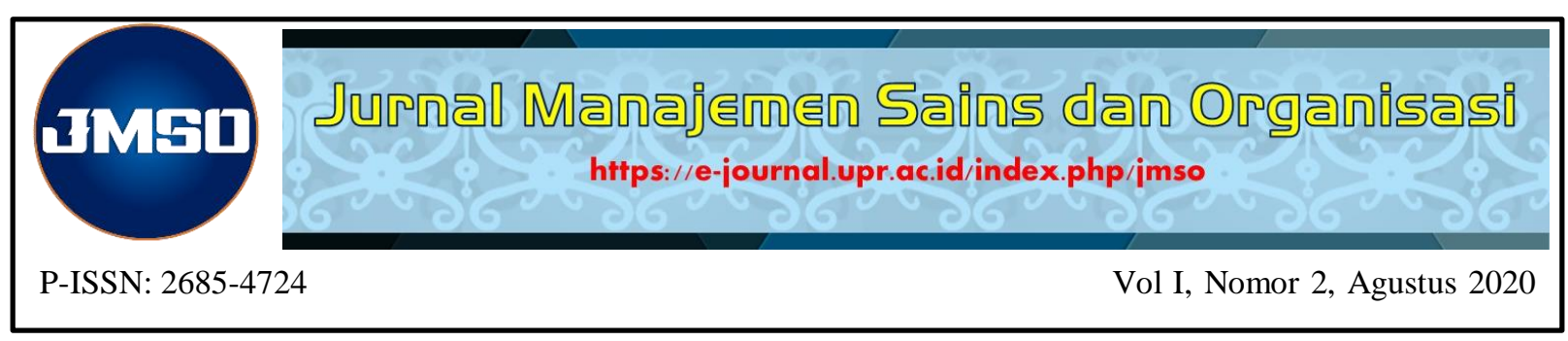

\title{
Pengaruh Kompensasi Dan Disiplin Kerja Terhadap Kinerja Karyawan Pada PT.Fajaray Kota Palangka Raya
}

\author{
Tindan 1) \\ Fakultas Ekonomi dan Bisnis \\ Universitas Palangka Raya, Indonesia \\ Rita Yuanita Toendan 2) \\ Fakultas Ekonomi dan Bisnis \\ Universitas Palangka Raya, Indonesia \\ Shinta Devi Ayu 3) \\ Fakultas Ekonomi dan Bisnis \\ Universitas Palangka Raya, Indonesia \\ Email: tindan.febupr.@gmail.com
}

\begin{abstract}
Abstrak
Tujuan - Penelitian ini bertujuan untuk mengetahui apakah terdapat pengaruh kompensasi dan disiplin kerja terhadap kinerja karyawan pada PT.Fajaray Multiraya kota Palangka Raya

Desain/Metodelogi/Pendekatan - Jumlah populasi adalah 30 orang, yang mana semua menjadi responden dalam penelitian ini. Penelitian ini menggunakan data primer yang diperoleh dengan penyebaran kuesioner kepada karyawan yang bekerja di PT.Fajaray Multiraya. Teknik analisis data yang digunakan dalam penelitian ini adalah regresi linier berganda, yang dioperasikan melalui progam SPSS 21 .

Temuan - Hasil penelitian ini menunjukan bahwa kompensasi berpengaruh terhadap kinerja karyawan, disiplin kerja berpengaruh terhadap kinerja karyawan. Sedangkan kompensasi dan disiplin kerja berpengaruh terhadap kinerja karyawan secara simultan.
\end{abstract}

Kata kunci: Kompensasi, disiplin kerja dan kinerja

\section{The Effect of Compensation and Work Discipline on Employee Performance at PT. Fajaray Kota Palangka Raya}

\begin{abstract}
Purpose - This study aims to determine whether there is an effect of compensation and work discipline on employee performance at PT. Fajaray Multiraya, Palangka Raya city.

Design / Methodology / Approach - The total population is 30 people, all of whom were respondents in this study. This study uses primary data obtained by distributing questionnaires to employees who work at PT. Fajaray Multiraya. The data analysis technique used in this study is multiple linear regression, which is operated through the SPSS 21 program.

Findings - The results of this study indicate that compensation affects employee performance, work discipline affects employee performance. Meanwhile, compensation and work discipline affect employee performance simultaneously.
\end{abstract}

Keywords: Compensation, work discipline and performance

Tindan, Rita Yuanita Toendan, Shinta Devi Ayu. Published in the Jurnal Manajemen sains dan Organsasi. Published by FEB UPR Publishing Limited. This article is published under the Creative Commons Attribution (CC BY 4.0) licence. Anyone may reproduce, distribute, translate and create derivative works of this article (for both commercial and non-commercial purposes), subject to full attribution to the original publication and authors. 


\section{PENDAHULUAN}

Saat ini sumber daya manusia tidak bisa dipandang sebelah mata dalam sebuah perusahaan. Karena sumber daya manusia menjadi salah satu unsur yang sangat penting bagi kehidupan suatu perusahaan atau organisasi, dimana maju - mundurnya suatu perusahaan ditentukan oleh sumber daya manusia yang dimiliki. Dengan memiliki sumber daya manusia yang terampil dan mampu bersaing, bisa menjadi salah satu faktor penentu kemajuan suatu perusahaan. Pada dasarnya untuk melihat sampai sejauh mana peranan sumber daya manusia dalam suatu perusahaan, maka dapat dilihat dari hasil kinerja seseorang karyawan yang ada dalam perusahaan tersebut. Karyawan yang memiliki kinerja yang tinggi dan baik dapat berkontribusi untuk mencapai tujuan serta sasaran-sasaran yang telah ditetapkan oleh perusahaan. Kinerja pada umumnya adalah hasil kerja yang dicapai oleh seseorang atau kelompok orang dalam suatu organisasi, sesuai dengan wewenang dan tanggung jawab masing-masing dalam rangka upaya mencapai tujuan organisasi bersanngkutan, secara legal tidak melanggar hukum dan moral maupun etika (Mathis \& Jackson,2009).

Dapat dikatakan semakin baik kinerja karyawan diperusahaan tersebut maka semakin mudah perusahaan mencapai tujuannya, dan sebaliknnya semakin rendahnya kinerja karyawan maka semakin sulitnya perusahaan mencapai tujuannya. Rendahnya tingginya kinerja karyawan dalam perusahaan dapat dilihat dari besar gaji maupun tunjangan yang diberikan oleh perusahaan. Mengingat sangat pentingnnya peran strategis sumber daya manusia maka perusahaan harus memanfaatkan SDM nya dengan efektif mungkin agar memiliki kinerja yang baik. Salah satunya dengan meningkatkan kinerja melalui pemberian kompensasi yang sesuai dengan balas jasa kepada karyawan atas usaha yang mereka lakukan kepada perusahaan.

Kompensasi adalah semua pendapatan yang berbentuk uang, barang langsung dan tidak langsung yang diterima karyawan sebagai imbalan atas jasa yang diberikan kepada perusahaan. Progam kompensasi mencerminkan upaya organisasi untuk mempertahankan sumber daya manusia yang dimiliki. Pemberian kompensasi yang baik akan mendorong karyawan untuk bekerja dengan makin baik dan produktif (Hasibuan,2012). Disamping kompensasi sebagai peningkatan kinerja karyawan ada hubungan yang sangat erat antara kompensi dengan disiplin kerja. Apabila karyawan memiliki kompensasi yang baik maka pada umumnya karyawan mempunyai disiplin kerja yang baik pula. Sebaliknya apa bila kompensasi yang di berikan kurang baik maka disiplin kerja akan rendah, karyawan dapat menyesuaikan diri dengan kebiasaankebiasaan yang tidak baik, misalnya mereka teralu banyak mengunakan waktu untuk keluar sekedar minum kopi, atau sering datang terlambat ke kantor (Moekijat, 2010).

Pimpinan perusahaan perlu mengawasi setiap perilaku maupun tindakan yang dilakukan oleh seluruh karyawan pada saat bekerja. Kedisiplinan adalah kesadaran dan kesedian seseorang dalam menaati semua peraturan perusahaan yang ada dan normanorma sosial yang berlaku. Adanya tingkat disiplin kerja yang baik akan mencermikan kredibilitas karyawan mencapai suatu hasil yang optimal untuk kessuksesan perusahaan (Hasibuan,2012).

Berdasarkan hasil wawancara yang dilakukan dengan beberapa karyawan di PT.Fajaray Multiraya kota Palangka Raya mengenai pemberian kompensasi dan penerapan disiplin kerja masih belum memberikan kepuasan sesuai apa yang di harapkan 
oleh karyawan dalam meningkatkan kinerja. Kompensasi merupakan hal yang sensitif bila dikaitkan dengan kelayakan dalam memenuhi kebutuhan, apalagi semakin besarnya tingkat kebutuhan saat ini, namun permasalahan yang dihadapi perusahaan yakini terikat dengan pemberian kompensasi diamana karyawan merasa adanya ketidak adilan. Ketidak adilan tersebut dikarenakan pemberian bonus pada karyawan tidak dilihat dari hasil kerjanya. Akibat dari adanya ketidak adilan yang dirasakan oleh karyawan akan berdampak pada kurang maksimalnya kinerja karyawan.

Kemudian dalam pelaksanaan disiplin kerja yang diterapkan oleh PT.Fajaray Multiraya saat ini masih terbilang kurang karena dapat dilihat dari beberapa hal, dimana masih terdapat karyawan yang hadir terlambat dan pulang sebelum jam kerja yang sudah ditentukan perusahaan dengan alasan yang tidak jelas, karyawa sering memanfaatkan pemberian tugas yang diberikan perusahaan untuk pergi menjalankan sebuah pekerjaan di luar kantor dan apabila pekerjaan tersebut sudah diselesaikan sebelum jam pulang kerja, karyawan seharusnya kembali ke kantor untuk memberikan laporan. Namun yang terjadi dalam perusahaan karyawan memilih untuk langsung pulang dibandingkan kembaili ke kantor. Sehingga dapat dilihat bahwa kedisiplinan kerja karyawan masih terbilang kurang. Dampak dari ketidak disiplinan tersebut mengakibatkan tugas yang harusnya dapat diselesaikan dengan lebih cepat menjadi tertunda, sehingga kinerja karyawan kurang optimal. Selain itu juga akan berdampak pada karyawan lainnya, karyawan lainnya akan merasa bahwa mereka pun bisa melakukan hal tersebut.

Ardana (2012) yang mengemukakan bahwa kompensasi adalah segala sesuatu yang diterima oleh karyawan sebagai balas jasa atas kontribusinya kepada perusahaan. Hadari Nawawi (2016) Kompensasi bagi organisasi atau perusahaan merupakan penghargaan/ganjaran pada para pekerja yang telah memberikan kontribusi dalam mewujudkan tujuan, melalui kegiatan yang disebut bekerja. Menurut Marwansyah (2014) Kompensaasi adalah penghargaan atau imbalan langsung maupun tidak langsung, finansial maupun nonfinansial yang adil dan layak kepada karyawan, sebagai balas jasa atas kontribusi/ jasanya terhadap pencapaian tujuan organisasi.Hasil penelitian dan analisis membuktikan bahwa Kompensasi menghasilkan nilai positif dan signifikan terhadap kinerja karyawan.

H1: Kompensasi menghasilkan nilai positif dan signifikan terhadap kinerja karyawan

Disiplin kerja menurut Hasibuan (2012) menyatakan kedisiplinan adalah kesadaran dan kesedian seseorang menaati semua peraturan perusahaan dan normanorma sosial yang berlaku. Menurut Rivai (2011), disiplin kerja adalah suatu alat yang dipergunakan para manajer untuk berkomunikasi dengan karyawan agar mereka bersedia untuk mengubah perilaku serta sebagai suatu upaya untuk meningkatkan kesadaran dan kesedian seorang dalam memenuhi segala peraturan perusahaan Hasil penelitian dan analisis membuktikan bahwa Dispensasi menghasilkan nilai positif dan signifikan terhadap kinerja karyawan.

H2: Dispensasi berpengaruh positif dan signifikan terhadap kinerja karyawan

Ardana (2012) yang mengemukakan bahwa kompensasi adalah segala sesuatu yang diterima oleh karyawan sebagai balas jasa atas kontribusinya kepada perusahaan. Hasil penelitian dan analisis membuktikan bahwa Kompensasi menghasilkan nilai positif dan signifikan terhadap kinerja karyawan. Sedangkan Menurut Rivai (2011), disiplin 
kerja adalah suatu alat yang dipergunakan para manajer untuk berkomunikasi dengan karyawan agar mereka bersedia untuk mengubah perilaku serta sebagai suatu upaya untuk meningkatkan kesadaran dan kesedian seorang dalam memenuhi segala peraturan perusahaan. Hasil penelitian membuktikan bahwa Kompensasi dan disiplin kerja berpengaruh positif dan simultan terhadap kinerja karyawan.

H3: Kompensasi dan disiplin kerja berpengaruh positif dan simultan terhadap kinerja karyawan

Gambar 1. Kerangka Berpikir

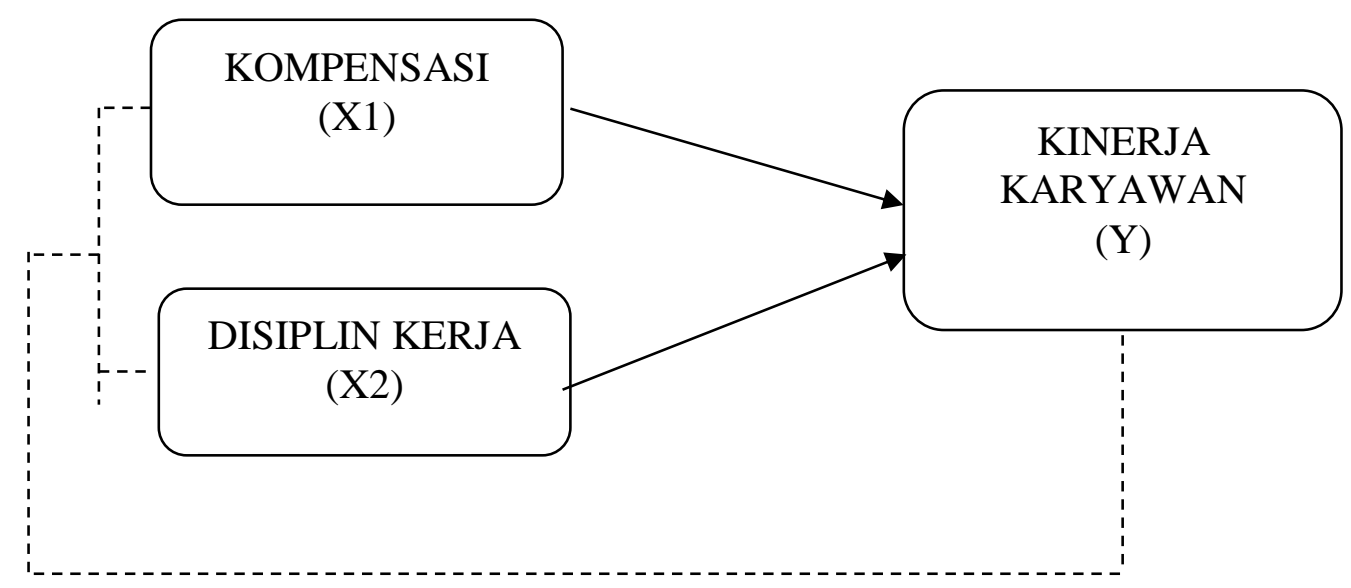

Keterangan :

$\longrightarrow \quad$ : Pengaruh Secara Parsial

: Pengaruh Secara Simultan

\section{Metode Penelitian}

Penelitian ini merupakan penelitian deskriptif-kuantitatif. Sumber data diperoleh dari penyebaran kusioner dan wawancara. Sampel dalam penelitian ini berjumlah sebanyak 30 orang karyawan pada PT.Fajaray Multiraya.

Variabel dan indikator yang digunakan dalam penelitian ini dapat dilihat dalam tabel berikut ini:

Tabel 2. Identifikasi Variabel

\begin{tabular}{lll}
\hline \multicolumn{1}{c}{ Variabel } & \multicolumn{1}{c}{ Definisi } & \multicolumn{1}{c}{ Indikator } \\
\hline mpensasi (X1) & mpensasi merupakan segala sesuatu & 1. Gaji \\
& bentuk imabalan yang diterima oleh & 2. Bonus \\
& seorang pekerja sebagai imbalan atas & 3. Tunjangan \\
& kerja mereka (Darsono \& siswandoko, & \\
& 2011) & \\
& iplin kerja merupakan sesuatu kekuatan & 1. Kehadiran Tepat Waktu \\
iplin Kerja (X2) & yang berkembang ditubuh para pekerja & 2. Menyelesaikan \\
& yang dapat membuat mereka dapat & pekerjaan tepat waktu \\
& mematuhi keputusan dan peraturan- & \\
\hline
\end{tabular}


peraturan yang telah ditetapkan Latinier (1983), dalam Rinoldy (2013).
3. Tanggung jawab terhadap tugas

4. Sikap dan Perilaku

\title{
nerja $(\mathbf{Y})$
}

\begin{abstract}
nerja adalah hasil kerja seseorang yang dicapai oleh seseorang dalam suatu organisasi, sesuai dengan wewenang dang tanggung jawab masing masing dalam rangka upaya mencapai tujuan organisasi bersangkutan, secara legal tidak melanggar hukum dan sesuai dengan moral Mathis \& Jackson (2009).
\end{abstract} 1. Kuantitas kerja 2. Kualitas kerja 3. Standar kerja 4. Rekan kerja

Sumber: Data sekunder dikembangkan, 2019

Data dianalisis dengan menggunakan metode statistik deskriptif dan regresi linier berganda yang dibantu dengan menggunakan progam SPPS versi 21.

\section{HASIL DAN PEMBAHASAN}

Berdasarkan data dari 30 responden melalui daftar pernyataan didapat kondisi responden tentang usia, jenis kelamin, pendidikan terakhir dan pendapatan perbulan. Penggolongan yang dilakukan terhadap responden dalam penelitian ini bertujuan untuk mengetahui secara jelas mengenai karakteristik responden sebagai objek penelitian. Gambaran objek penelitian tersebut satu persatu dapat di uraikan sebagai berikut :

Tabel 3. Karakteristik Responden

\begin{tabular}{|c|c|c|}
\hline Uraian & Frekuensi & Persentase \% \\
\hline \multicolumn{3}{|l|}{ Usia: } \\
\hline 21 tahun - 30 tahun & 13 & $43 \%$ \\
\hline 31 tahun - 50 tahun & 17 & $57 \%$ \\
\hline Total & 30 & $100 \%$ \\
\hline \multicolumn{3}{|l|}{ Jenis Kelamin: } \\
\hline Laki-laki & 21 & $70 \%$ \\
\hline Perempuan & 9 & $30 \%$ \\
\hline Total & 30 & $100 \%$ \\
\hline \multicolumn{3}{|l|}{ Pendidikan Terakhir: } \\
\hline SMA/SMK/Sederajat & 3 & $10 \%$ \\
\hline D3 & 7 & $24 \%$ \\
\hline S1 & 20 & $66 \%$ \\
\hline Total & 30 & $100 \%$ \\
\hline \multicolumn{3}{|l|}{ Lama Bekerja: } \\
\hline $1-2$ & 3 & $10 \%$ \\
\hline $3-4$ & 6 & $20 \%$ \\
\hline$>5$ & 21 & $70 \%$ \\
\hline Total & 30 & $100 \%$ \\
\hline \multicolumn{3}{|l|}{ Besaran Gaji: } \\
\hline Rp. 1.000 .000 - Rp. 2.000 .000 & 4 & $13 \%$ \\
\hline Rp. 2.000.000 - Rp. 3.000.000 & 16 & $53 \%$ \\
\hline > Rp. 3.000.000 & 10 & $34 \%$ \\
\hline Total & 30 & $100 \%$ \\
\hline
\end{tabular}

Sumber: Data primer diolah, 2019 
Berdasarkan Tabel 3 dapat dilihat dapat di ketahui bahwa mayoritas responden usia yang dimiliki responden paling banyak adalah 31-50 tahun terdapat 17 responden dengan persentase 57\% sedangkan pada umur 21-30 tahun terdapat 13 responden dengan persentase $43 \%$. Selain itu diketahui bahwa 21 responden atau $70 \%$ berjenis kelamin lakilaki dan 9 responden atau 30\% berjenis kelamin perempuan. Dengan tingkat pendidikan terakhir responden paling banyak adalah sarjana sebanyak 20 responden dengan persentase 66\%, dan terendah adalah SMA/SMK Sederajad 3 responden dengan persentase $10 \%$. Serta terdapat 21 responden atau $70 \%$ sudah bekerja lebih dari 5 tahun dan 3 responden atau 10\% sudah bekerja selama 1-2 tahun. Dan sebanyak 10 responden dengan persentase $34 \%$ memiliki gaji > 3 juta dan 16 responden dengan persentase $53 \%$ memiliki gaji 2-3 juta sedangkan 4 responden dengan persentase $13 \%$ memiliki gaji 1-2 juta.

\section{Uji Instrumen Penelitian}

Adapun rangkuman hasil uji validitas dan hasil uji reliabilitas dapat dilihat pada Tabel 4. dan Tabel 5. sebagai berikut:

Tabel 4. Hasil Uji Validitas

\begin{tabular}{llll}
\hline Item & r Hitung & r Tabel & Keterangan \\
\hline X1.1 & 0.939 & 0.3610 & Valid \\
X1.2 & 0.925 & 0.3610 & Valid \\
X1.3 & 0.908 & 0.3610 & Valid \\
X2.1 & 0.805 & 0.3610 & Valid \\
X2.2 & 0.672 & 0.3610 & Valid \\
X2.3 & 0.904 & 0.3610 & Valid \\
X2.4 & 0.743 & 0.3610 & Valid \\
Y1 & 0.874 & 0.3610 & Valid \\
Y2 & 0.956 & 0.3610 & Valid \\
Y3 & 0.881 & 0.3610 & Valid \\
Y4 & 0.956 & 0.3610 & Valid \\
\hline
\end{tabular}

Berdasarkan Tabel 4. Berdasarkan hasil uji validitas pada tabel 4.6 diatas dapat dilihat menunjukan bahwa seluruh pernyataan dalam variabel kompensasi (X1), Disiplin Kerja (X2) dan Kinerja Karyawan (Y) adalah Valid. Hal ini terlihat bahwa nilai person correlation rhitung $>$ rtabel dengan tingkat signifikan untuk semua item 0.05.

Tabel 5. Hasil Uji Reliabilitas

\begin{tabular}{lll}
\hline Variabel & Cronbach Alpha & Keterangan \\
\hline Kompensasi (X1) & 0.914 & Reliabel \\
Disiplin Kerja (X2) & 0.792 & Reliabel \\
Kinerja Karyawan (Y) & 0.938 & Reliabel \\
\hline Sumber: Hasil Olahan SPSS 21 & &
\end{tabular}


Berdasarkan hasil uji reliabilitas pada tabel 5, instrument kuesioner reliable, nilai yang dicapai masing-masing variable > 0.60 artinya instrument dapat digunakan.

\section{Uji Asumsi Klasik \\ Uji Normalitas}

Menurut Duwi Priyatno (2012) model regresi yang baik adalah yang memiliki nilai residual yang terdistribusi secara normal. Uji normalitas pada penelitian ini menggunakan grafik normal p-p plot of regression standardized residual. Sebagai dasar pengambilan keputusannya, jika data (titik-titik) menyebar sekitar garis dan mengikuti garis diagonal maka nilai residual tersebut telah normal (Duwi Priyatno, 2012) dan uji Kolmogorov-Smirnov dari tabel One-Sample Kolmogorov-Smirnov Test diperoleh angka probabilitas atau Asym. Sig (2-tailed) dengan taraf signifikan 0,05. Hasil analisis multikolinieritas dapat dilihat pada tabel 6 berikut :

Tabel 6. Uji Normalitas

One-Sample Kolmogorov-Smirnov Test

\begin{tabular}{llr}
\hline & & $\begin{array}{r}\text { Unstandardized } \\
\text { Residual }\end{array}$ \\
\hline $\mathrm{N}$ & Mean & 30 \\
Normal Parameters &, 0000000 \\
& Std. Deviation & 1,30733522 \\
Most Extreme Differences & Absolute &, 089 \\
& Positive &, 066 \\
Test statistic & Negative &, 089 \\
Asymp. Sig. (2-tailed) &, 089 \\
\hline a. Test distribution is Normal. &, 971 \\
b. Calculated from data. & \\
c. Lilliefors Significance Correction & \\
Sumber: Hasil Olahan SPSS 21 &
\end{tabular}

Berdasarkan hasil uji normalitas bahwa nilai signifikansi Asymp Sig (2tailed) sebesar 0,971 sedangkan taraf signifikansinya adalah 0.05 nilai signifikansi yang di hasilkan adalah 0,971>0,05 maka residual berdistribusi normal.

\section{Uji Multikolinearitas}

Uji Multikolinieritas digunakan untuk menguji apakah antara variabel bebas memiliki hubungan yang sempurna atau tidak, syarat diterimanya model regresi berganda apabila antara variabel bebas tidak mengandung korelasi yang sempurna. Pengujian multikolinieritas dapat dilihat dari nilai variance inflance factor (VIF) berdasarkan hasil output SPSS. Apabila nilai VIF $<10,00$ dan mendekati 1 dapat disimpulkan bahwa asumsi adanya multikolinieritas ditolak. Hasil analisis multikolinieritas dapat dilihat pada tabel 7 berikut : 
Tabel 7. Uji Multikolinearitas

\begin{tabular}{|c|c|c|c|c|c|c|c|}
\hline \multicolumn{8}{|c|}{ Coefficients $^{\mathrm{a}}$} \\
\hline \multirow[t]{2}{*}{ Model } & \multicolumn{2}{|c|}{$\begin{array}{c}\text { Unstandardized } \\
\text { Coefficients }\end{array}$} & $\begin{array}{l}\text { Standardized } \\
\text { Coefficients }\end{array}$ & \multirow[t]{2}{*}{$\mathrm{t}$} & \multirow[t]{2}{*}{ Sig. } & \multicolumn{2}{|c|}{$\begin{array}{l}\text { Collinearity } \\
\text { Statistics }\end{array}$} \\
\hline & $\mathrm{B}$ & Std. Error & Beta & & & Tolerance & VIF \\
\hline (Constant) & 3,422 & 1,837 & & 1,862 & ,073 & & \\
\hline $\mathrm{X} 1$ & 1,251 & , 102 & 881 & 12,294 &, 000 & 961 & 1,040 \\
\hline $\mathrm{x} 2$ & 341 & 140 & ,174 & 2,427 & 022 & ,961 & 1,040 \\
\hline
\end{tabular}

Dependent Variable: $Y$

Sumber: Hasil Olahan SPSS 21

Berdasarkan hasil penelitian diperoleh nilai Tolerence untuk variabel menunjukan variabel kompensasi dan disiplin kerja memiliki nilai 0,961 kedua nilai ini Tolerance dari variabel diatas > 0,10 dan nilai VIF untuk variabel kompensasi dan disiplin kerja yaitu 1,040. Kedua nilai VIF variabel diatas $<10,00$, yang berarti bahwa model regresi tidak mengandung multikolinieritas.

\section{Uji heterokedastisitas}

Uji heterokedastisitas bertujuan menguji apakah dalam model regresi terjadi ketidaksamaan variabel dari residual satu pengamatan ke pengamatan lain tetap, maka disebut homokedastisitas dan jika berbeda disebut heteroskedastisitas. Untuk lebih menyakinkan, uji statistik diperlukan yaitu dengan Uji Gletser, jika hasil uji Gletser menunjukkan nilai signifikan yang lebih besar dari nilai signifikan yang digunakan dalam penelitian yaitu 0,05 maka tidak terjadi hesteroskadatisitas, sebaliknya nilai signifikan hasil perhitungan lebih kecildari 0,05 maka terjadi gejala hesteroskadatisitas.

\section{Coefficients ${ }^{a}$}

Tabel 8. Uji Heterokedastisitas

\begin{tabular}{|c|c|c|c|c|c|c|}
\hline \multirow{2}{*}{\multicolumn{2}{|c|}{ Model }} & \multicolumn{2}{|c|}{ Unstandardized Coefficients } & \multirow{2}{*}{$\begin{array}{l}\text { Standardized } \\
\text { Coefficients } \\
\text { Beta }\end{array}$} & \multirow[t]{2}{*}{$\mathrm{t}$} & \multirow[t]{2}{*}{ Sig. } \\
\hline & & $\overline{\mathrm{B}}$ & Std. Error & & & \\
\hline \multirow{3}{*}{1} & (Constant) & ,828 & 1,069 & & ,775 & 4,445 \\
\hline & $\mathrm{X} 1$ &, 035 & 059 & , 116 & ,593 & ,558 \\
\hline & $\mathrm{X} 2$ &,- 014 & ,082 &,- 032 &,- 166 & 870 \\
\hline
\end{tabular}

a. Dependent Variable: RES2

Sumber: Hasil Olahan SPSS 21

Berdasarkan Tabel 8 terlihat nilai sig pada $\mathrm{X}_{1}$ sebesar 0,558 dan $\mathrm{X}_{2}$ sebesar 0,870. Karena nilai sig lebih besar dari 5\% artinya variabel kompensasi $\left(\mathrm{X}_{1}\right)$ dan disiplin kerja $\left(\mathrm{X}_{2}\right)$ tidak terjadi heteroskedastisitas.

\section{Analisis Regresi Linear Berganda}

Penelitian ini menggunakann regresi linear berganda untuk pembuktian hipotesis 
penelitian. Analisis ini menggunakan input berdasarkan data yang diperoleh dari kuesioner. Hasil pengelolahan data sebagai berikut :

Tabel 9. Hasil Regresi Linear Berganda

Coefficients $^{a}$

\begin{tabular}{|c|c|c|c|c|c|c|}
\hline \multirow{2}{*}{\multicolumn{2}{|c|}{ Model }} & \multicolumn{2}{|c|}{$\begin{array}{c}\text { Unstandardized } \\
\text { Coefficients }\end{array}$} & \multirow{2}{*}{$\begin{array}{c}\text { Standardized } \\
\text { Coefficients } \\
\text { Beta }\end{array}$} & \multirow[t]{2}{*}{$\mathrm{T}$} & \multirow[t]{2}{*}{ Sig. } \\
\hline & & $B$ & Std. Error & & & \\
\hline \multirow{3}{*}{1} & (Constant) & $-3,422$ & 1,837 & & $-1,862$ & ,073 \\
\hline & $\mathrm{X} 1$ & 1,251 & , 102 & ,881 & 12,294 & ,000 \\
\hline & $\mathrm{X} 2$ & ,341 & , 140 & , 174 & 2,427 & ,022 \\
\hline
\end{tabular}

a. Dependent Variable: $Y$

Sumber: Hasil Olahan SPSS 21

Hasil analisis regresi linear berganda dengan progam SPPS, seperti terlihat padatable di atas pada kolom Unstandardized Coefficients bagian B, maka diperoleh persamaan regresi linier berganda sebagai berikut:

$\mathrm{Y}=-3,422+1,251 \mathrm{X} 1+0,341 \mathrm{X} 2$

Berdasarkan hasil persamaan regresi linear berganda di atas, maka dapat dianalisis sebagai berikut: Konstanta sebesar -3,422, variabel kompensasi dan disiplin kerja bernilai 0, maka kinerja karyawan akan bernilai sebesar -3,422. Sehingga dapat di simpulkan bahwa tanpa ada variabel kompensasi dan disiplin kerja maka kinerja karyawan akan srbesar $-3,422$ berpengaruh negatif. Koefisien regresi kompensasi (X1) Sebesar 1,251, artinya jika kompensasi (X1) mengalami kenaikan atau penambahan $1 \%$, maka kinerja karyawan akan naik sebsar 1,251. Koefisien regresi disiplin kerja (X2) sebesar 0,341, artinya jika disiplin kerja (X2) mengalami kenaikan atau penambahan sebesar 1\%, maka akan meningkatkan kinerja karyawan (Y) sebesar 0,341.

\section{Uji Hipotesis}

\section{Uji T}

Pengujian hipotesis dilakukan dengan uji parsial (uji t). Uji t digunakan untuk mengetahui pengaruh variabel bebas dan variabel terikat secara parsial.

Tabel 10. Hasil Uji T ( Uji Parsial )

Coefficients $^{\mathrm{a}}$

\begin{tabular}{clllll}
\hline \multirow{2}{*}{ Model } & \multicolumn{2}{l}{$\begin{array}{l}\text { Unstandardized } \\
\text { Coefficients }\end{array}$} & $\begin{array}{l}\text { Standardized } \\
\text { Coefficients }\end{array}$ & t & \multirow{2}{*}{ Sig. } \\
\cline { 2 - 4 } & $\mathrm{B}$ & Std. Error & Beta & & \\
\hline (Constant) & $-3,422$ & 1,837 & & $-1,862$ &, 073 \\
X1 & 1,251 &, 102 &, 881 & 12,294 &, 000 \\
X2 &, 341 &, 140 &, 174 & 2,427 &, 022 \\
\hline
\end{tabular}

a. Dependent Variable: Y

Sumber: Hasil Olahan SPSS 21

$\mathrm{T}$ tabel $=\mathrm{t}(0,05 / 2: 30-2-1)=\mathrm{t}(0,025: 27)=2,051$. Pada uji $\mathrm{t}$ diperoleh nilai 
thitung masing-masing variabel. Nilai thitung tersebut selanjutnya dibandingkan dengan nilai ttabel pada $\alpha=0,05$ adalah 2,051 sebagai berikut: Hasil pengujian secara parsial antara variabel kompensasi terhadap kinerja karyawan menunjukan thitung 12,294> ttabel sebesar 2,051 dengan sig 0,000 < 0,05 maka H0 ditolak Ha diterima. Artinya variabel kompensasi mempunyai pengaruh yang sigifikan terhadap kinerja karyawan. Hasil pengujian secara parsial antara variabel disiplin kerja terhadap kinerja karyawan menunjukkan thitung 2,427 > ttabel 2,051 dengan sig 0,022<0,05 maka H0 ditolak Ha diterima. Artinya variabel disiplin kerja mempunyai pengaruh yang signifikan terhadap variabel kinerja karyawan.

\section{Uji F (Uji Simultan)}

Uji F dilakukan untuk mengetahui pengaruh masing-masing variabel independen secara simultan terhadap variabel dependen. Dalam pengujian ini $F_{\text {hitung }}$ dibandingkan dengan $\mathrm{F}_{\text {tabel, }}$ dimana jika $\mathrm{F}_{\text {hitung }}>\mathrm{F}_{\text {tabel }}$ maka hipotesis diterima, artinya variabel bebas secara simultan mempunyai pengaruh terhadap variabel terikat sebaliknya, jika $F_{\text {hitung }}$ $<\mathrm{F}_{\text {tabel }}$ maka hipotesis ditolak. Taraf signifikan yang digunakan adalah $\alpha=0,05$.

Tabel 11. Hasil Uji F (Uji Simultan)

\begin{tabular}{|c|c|c|c|c|c|}
\hline \multicolumn{6}{|c|}{ ANOVA $^{a}$} \\
\hline Model & Sum of Squares & Df & Mean Square & $\mathrm{F}$ & Sig. \\
\hline Regression & 322,302 & 2 & 161,151 & 87,786 &, $000^{\mathrm{b}}$ \\
\hline 1 Residual & 49,565 & 27 & 1,836 & & \\
\hline Total & 371,867 & 29 & & & \\
\hline
\end{tabular}

F tabel $=3,35$ diperoleh berdasarkan df pembilang $=3-1=2$. Df penyebut 30 $-3=27$ dan $\alpha=0,05 \%$ sehingga diperoleh $F$ tabel $=3,35$. Karena Fhitung $(87,789)>$ Ftabel $(3,35)$ atau sig 0,000 < 0,05 maka H0 ditolak dan Ha diterima, artinya variabel bebas kompensasi (X1) dan disiplin kerja (X2) secara simultan berpengaruh terhadap variabel terikat yaitu kinerja karyawan (Y), dengan kata lain

\section{Koefisien Determinasi (R2)}

Koefisien determinasi pada regresi linier berganda adalah digunakan untuk mengetahui seberapa besar kontribusi yang diberikan variabel bebas $(\mathrm{X})$ terhadap perubahan variabel terikat $(\mathrm{Y})$. Nilai koefisien determinasi ditentukan dengan nilai $\mathrm{R}$ square pada tabel berikut :

Tabel 12. Hasil Uji Koefisien Determinasi (R2)

\section{Model Summary}

\begin{tabular}{ccccc}
\hline Model & $\mathrm{R}$ & $\begin{array}{c}\mathrm{R} \\
\text { Square }\end{array}$ & $\begin{array}{c}\text { Adjusted R } \\
\text { Square }\end{array}$ & Std. Error of the Estimate \\
\hline 1 & $.931^{\mathrm{a}}$ & .867 & .857 & 1.35489 \\
\hline \multicolumn{3}{l}{ a. Predictors: (constant), X2, X1 } \\
Sumber: Hasil Olahan SPSS 21
\end{tabular}


Diperoleh koefisien determinasi $\left(R^{2}\right)$ sebesar 0,867 artinya variabel kompensasi dan disiplin kerja memberikan sumbangan terhadap naik turunnya kinerja karyawan sebesar $86,7 \%$ sedangkan sisanya $13,3 \%$ dipengaruhi oleh variabel-variabel lain diluar model penelitian.

Berdasarkan hasil analisis diatas maka fenomena yang terjadi pada koperasi karyawan PT. Fajaray Multiraya kota Palangka Raya dapat disimpulkan bahwa: kompensasi mempunyai pengaruh yang signifikan terhadap kinerja karyawan PT.Fajaray Multiraya kota Palangka Raya. Hal ini dibuktikan dengan uji t antara variabel kompensasi dengan variabel kinerja karyawan diamana thitung sebesar 12,294 > ttabel sebesar 2,051 artinya variabel kompensasi berpengaruh terhadap kinerja karyawan. Disiplin kerja mempunyai pengaruh yang signifikan terhadap kinerja karyawan PT.Fajaray Multiraya kot Palangka Raya. Hal ini dibuktikan dengan uji t antara variabel disiplin kerja dengan variabel kinerja karyawan dimana t hitung sebesar 2,427 > ttabel sebesar 2,051 artinya variabel disisplin kerja berpengaruh terhadap kinerja karyawan. Kompensasi dan disiplin kerja mempunyai pengaruh yang signifikan terhadap kinerja karyawan pada PT. Fajaray Multiraya kota Palangka Raya, hal ini dubuktikan dengan uji $\mathrm{F}$ antara variabel kompensasi dan disiplin kerja dengan variabel kinerja karyawan dengan nilai signifikan sebesar 0,000 dan hasil ini lebih kecil dari 0.05 atau 5\%. Selain itu hubungan kedua variabel dapat diketahui dari nilai $\mathrm{F}$ hitung sebesar 87,786 > dari F tabel sebesar 3,35. Kesimpulannya dalah variabel kompensasi dan disiplin kerja berpengaruh terhadap kinerja karyawan.

\section{SIMPULAN}

Penelitian ini memberikan bukti empiris kompensasi berpengaruh secara parsial terhadap kinerja karyawan pada PT.Fajaray Multiraya Kota Palangka Raya. Yang artinya kompensasi memberikan pengaruh terhadap kinerja karyawan pada PT.Fajaray Multiraya. Disiplin Kerja berpengaruh sacara parsial terhadap kinerja karyawan pada PT.Fajaray Multiraya kota Palangka Raya. Yang artinya disiplin kerja memberikan pengaruh terhadap kinerja karyawan pada PT. Fajaray Multiraya. Kompensasi dan Disiplin Kerja berpengaruh secara simultan terhadap Kinerja Karyawan pada PT.Fajaray Multiraya kota Palangka Raya. Hal ini berarti bahwa kompensasi (X1) dan disiplin kerja (X2) dapat meningkatkan kinerja karyawan (Y) pada PT.Fajaray Multiraya.

Saran yang dapat diberikan berdasarkan hasil penelitian adalah diharapkan penelitian ini dapat dijadikan pertimbangan untuk mengatasi masalah yang terjadi pada karyawan PT. Fajaray Multiraya kota Palangka Raya. Untuk pemberian Kompensasi sebaiknya di lakukan secara adil kepada setiap karyawan agar karyawan merasa lebih dihargai atas usaha kerja yang di curahkannya untuk perusahaan. Selain itu untuk masalah Kedisiplinan Kerja pimpinan PT. Fajaray Multiraya harus lebih memperhatikan setiap karyawan agar setiap karyawan memiliki rasa tanggung jawab dalam bekerja. Dan untuk meningkatkan Kinerja karyawan harus dibangun hubungan kerja yang baik antara rekan kerja. Hal ini akan mendorong terciptanya kinerja karyawan yang baik dan maksimal

Penelitian selanjutnya diharapkan untuk mengembangkan penelitian ini dengan menggunakan populasi dan sampel yang lebih luas agar hasil penelitian lebih teruji kendalanya. 


\section{REFERENSI}

Ardana, I Komang.et al. 2012. Manajemen Sumber Daya Manusia. Yogyakarta: Graha Ilmu.

Darsono dan Tjatjuk, Siswandoko. 2011. Manajemen Sumber Daya Manusia Abad 21. Jakarta: Nusantara Consulting.

Hasibuan, Melayu SP. 2012. Manajemen Sumber Daya Manusia - Edisi Revisi. Cetakan Keenam Belas. Jakarta: PT. Bumi Aksara.

Henry, Sinamora. 2004. Manajemen Sumber Daya Manusia - Edisi Ketiga. Yogyakarta: STIE YPKN.

Mathis, L. R., dan Jackson, H.J. 2009. Human Resource Management Manajemen Sumber Daya Manusia ). Edisi Sepuluh.

Jakarta: Salemba Empat.

Marwansyah. 2014. Manajemen Sumber Daya Manusia - Edisi Kedua. Cetakan Ketiga. Bandung: CV. Alfabeta.

Moekijat. 2010. Manajemen Sumber Daya Manusia. Cetakan Kesembilan. Bandung: CV. Mandar Maju.

Nawawi, Hadari. 2016. Manajemen Sumber Daya Manusia untuk Bisnis yang Kompetitif. Cetakan Kesembilan. Yogyakarta: Gadjah Mada University Press.

Notoadmodjo, Soekidjo. 2001. Pengembangan Sumber Daya Manusia. Jakarta: Rineka Cipta.

Rinoldy, Z. 2013. Pengaruh disiplin kerja dan kemampuan kerja terhadap kinerja pegawai dinas pertanian pertenakan perikanan dan kehutanan kota jambi. Jurnal dinamika manajemen, ISSN 2338 - 123X Vol.1 No.1, 2013

Rivai, Velthza. 2003. Manajemen Sumber Daya Manusia untuk Perusahaan Dari Teori ke Praktik. Jakarta: PT. Rajagrafindo Persada.

Sinambela, Lijan. 2012. Kinerja Pegawai Teori Pengukuran dan Implikasi. Yogyakarta: Graha Ilmu.

Sugiyono. 2009. Metode Penelitian dan Bisnis. Cetakan ketiga Belas. Bandung: CV. Alfabeta.

Suwati, Yuli. 2013. Pengaruh Kompensasi dan Motivasi Terhadap Kinerja Karyawan PT. Tunas Hijau Samarinda. Skripsi Universitas Mulawarman, Samarinda

Umar, Husein. 2008. Desain Penelitian Manajemen Sumber Daya Manusia dan Perilaku Karyawan Paradigma Positivik dan Berbasis Pemecahan Masalah. Jakarta: PT. Raja Grafindo Perda.

Utami, F. R. 2014. Pengaruh Kompensasi dan Disiplin Kerja Terhadap Kinerja Karyawan PT. Gapura Omega Alpha Land Depok. Skripsi Universitas Isalam Negeri Syarif Hidayatullah, Jakarta

Veitzal dan Sagala Juavani. 2009. Manajemen Sumber Daya Manusia untuk Perusahaan. Jakarta: Rajawali Pers. 